\title{
EPHEMERUM SPINULOSUM BRUCH \& SCHIMP. (BRYOPHYTA), A NEW SPECIES FOR RUSSIA
}

\section{EPHEMERUM SPINULOSUM BRUCH \& SCHIMP. (BRYOPHYTA) - НОВЫЙ ВИД ДЛЯ РОССИИ}

\author{
Michael S. IGNATOV ${ }^{1}$, Elena A. IGNATOVA ${ }^{2}$ \& ElenA V. MALASHKinA ${ }^{1}$ \\ МИХАИЛ С. ИГНАТОВ ${ }^{1}$, ЕЛЕНА А. ИГНАТОВА ${ }^{2}$, ЕЛЕНА В. МАЛАШКИНА ${ }^{1}$
}

Abstract

Ephemerum spinulosum is newly recorded for Russia. It was collected in the Russian Far East (Primorsky Territory, Lozovy Mt. Range) in the same locality where earlier we found Fissidens hyalinus. Description, illustration and comments on species habitat are provided, and its general distribution is discussed.

Резюме

Ephemerum spinulosum впервые приводится для России. Он был обнаружен в Приморском крае на Лозовом хребте, в месте, где недавно был собран Fissidens hyalinus. Приводятся описание и иллюстрации вида по материалу из России, а также обсуждается его общее распространение.

KEYWORDS: Ephemerum spinulosun, mosses, biogeography, Russia.

In September 2013 we were able to visit Lozovyj Mountain Range (former called Chandolaz Mountain), in the southern Russian Far East (Figs. 1-4). This is an interesting calcareous region where in September 2007 we found Fissidens hyalinus Hook. \& Wilson, a mostly tropical and subtropical moss which was not known in Russia before that time (Ignatov et al., 2007). That first finding has been done also in August, and plants were mostly quite young, with 2-3 leaves only and in sterile state, indicating that this is a species late in seasonal development. So in the second visit, we looked for better developed plants, but they were found again in about the same state. Considering to obtain better developed plants, we have taken a number of soil pieces with young shoots of Fissidens and after several days, in Moscow, put them in Petri dish, leaving at the window, moderately moistening them. As an admixture to this Fissidens, there were scattered plants of Weissia longifolia Mitt. and another small capsule bearing species with immature sporophytes (Fig. 5). After few days of cultivation in Petri dish at the window capsules of this latter species turned to brownish color, spores became mature and we were able to identify it as Ephemerum spinulosum Bruch \& Schimp.

This is the first record of species in Russia and the first record of the family Ephemeraceae in asian part of Russia. The genus Ephemerum is represented in the country by only one more species, E. serratum (Hedw.) Hampe, which is known by scattered records in central and northwest european Russia (Ignatov, Afonina, Ignatova et al., 2006; Ignatov \& Ignatova, 2003).
Ephemerum spinulosum Bruch \& Schimp. in Schimp., Syn. Musc. Eur. 6. 1860. Fig. 6.

Plants very small, female plants with sporophytes $1[-$ $2.5] \mathrm{mm}$ high, pale green, growing as scattered individuals among abundant persistent protonema. Stem almost absent. Leaves forming a rosette, lanceolate to linear-lanceolate, longly acuminate, $0.8-1.0[-1.4] \times 0.15-0.2[-0.4]$ $\mathrm{mm}$; costa \pm wide but weak, subpercurrent, disappearing in basal part of leaf, in transverse section consisting of 23 layers of undifferentiated cells, surface cells indistinguishable from adjacent laminal cells, on dorsal side with strongly protruding angles, spinulose; margins plane, strongly serrate in upper $1 / 3$, often with recurved teeth, serrate in the middle part and weakly serrulate in basal $1 /$ 3 of leaf; lamina unistratose, upper laminal cells $30-50 \times 9$ $12 \mu \mathrm{m}$, with strongly protruding upper angles on dorsal side, median laminal cells $25-55 \times 10-13 \mu \mathrm{m}, \pm$ smooth, basal laminal cells $35-60 \times 9-18 \mu \mathrm{m}$, smooth. Dioicous or rhizautoicous, male plants not observed in collection from Russia [smaller than female plants]. Seta very short. Capsule immersed in perichaetial leaves, sessile, spheric, ca. 0.3$0.4 \mathrm{~mm}$ in diameter, cleistocarpous; exothecial cells isodiametric to short rectangular, thin-walled, stomata few. Spores ovoid, $50-55 \times 38-40 \mu \mathrm{m}$, finely papillose. Calyptra mitrate. Rhizoidal tubers not seen.

Specimen examined: RUSSIA, Primorsky Territory, Lozovyj Mt. Range, northern slope, $43^{\circ} 00^{\prime} 05.4^{\prime} \mathrm{N}, 133^{\circ} 00^{\prime} 40.6^{\prime} \mathrm{E}, 260$ $\mathrm{m}$ alt., 8.IX.2013, Ignatov, Ignatova \& Malashkina \#13-1175 (MHA).

1 - Main Botanical Garden, Russian Academy of Sciences, Botanicheskaya 4, Moscow 127276 Russia - Россия 127276 Москва, Ботаническая, 4, Главный ботанический сад РАH, e-mail: misha ignatov@list.ru, 345901@gmail.com

2 - Moscow State University, Biological Faculty, Geobotany Dept., Moscow 119234 Russia - Россия 119234, Москва, Московский университет, Биологический факультет, каф. геоботаники; е-mail: arctoa@list.ru 

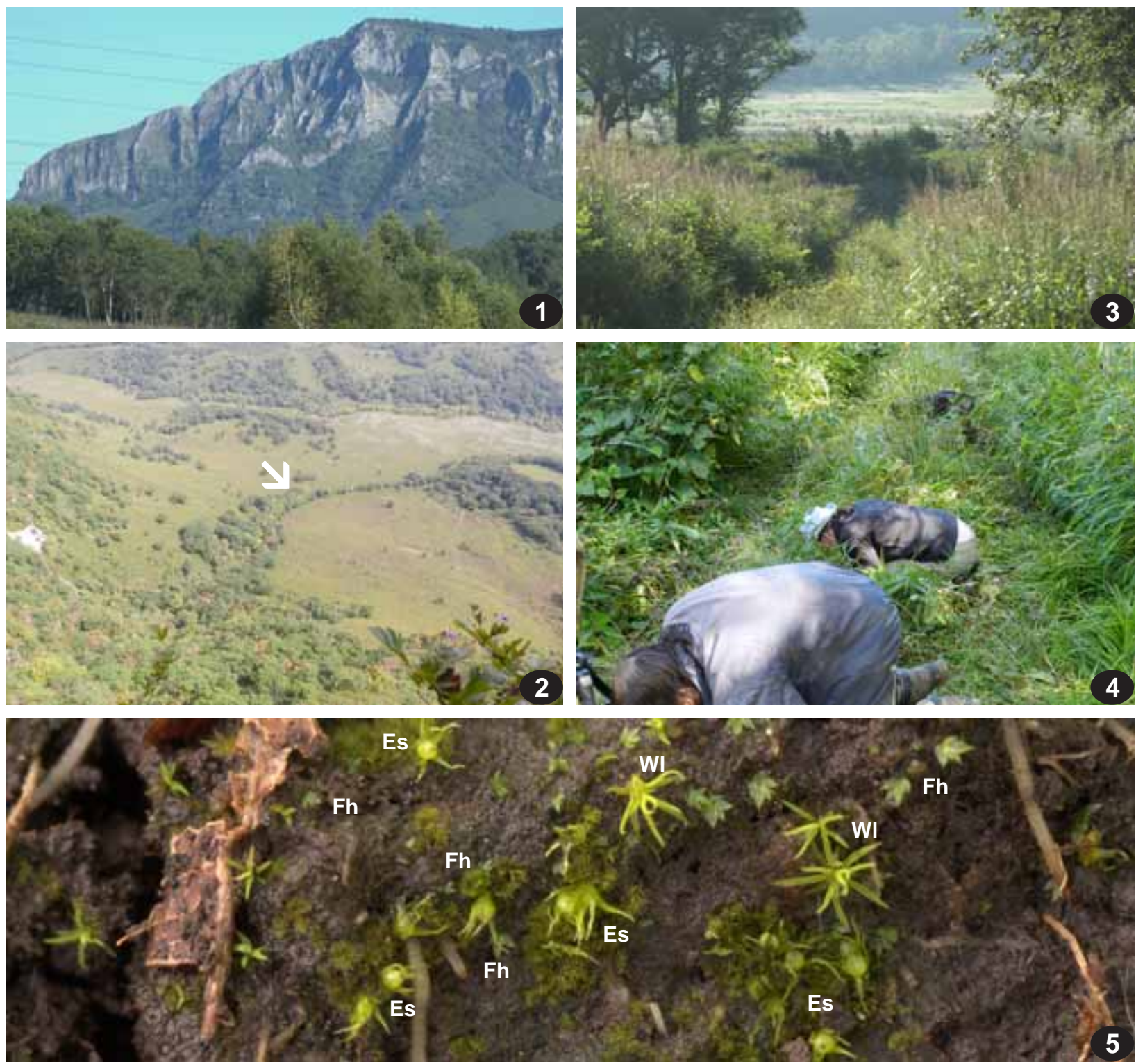

Figs. 1-5. Ephemerum spinulosum locality: 1: Lozovyj Mt. Range; 2: photo from cliff at\#1 on foothill, the locality of the species arrowed; 3-4: habitat close up; 5: in situ photo by Oleg Ivanov: Es - Ephemerum spinulosum; Fh - Fissidens hyalinus; W1 - Weissia longifolia.

Ecology. The plant was collected on open N-faced slope of calcareous mountain range covered with dense thickets of tall shrub Lespedeza bicolor Turcz., on a rarely used grassy road, on a small patch of rather solid bare soil among grasses. The place is generally dry, with very few brooks running from the range slope; however the road was in ca. $30 \mathrm{~m}$ beside a brook.

In North America, habitats of E. spinulosum are described as rather variable, but often moist: "sides of ditches and ravines, moist paths, old fields, swamps, moist or drying soil in disturbed, partly sunny areas, occasionally on rotten wood" (Bryan, 2007). Noguchi \& Iwatsuki (1988) also indicate its growth on moist soil on fallow fields. Similarly, in Spain and in Ireland it was found on a damp silty mud at the banks of water reservoirs (Sérgio, 2010; Lockhart et al., 2012). Thus, the habitat of the species in Primorsky Territory is comparatively dryier, and its finding in such place could hardly be expect- ed. However, a monsoon climate of the region may provide a sufficient amount of moisture for its development in rainy season.

Variation. Noguchi \& Iwatsuki (1988) mention that Japanese populations of E. spinulosum differ from North American ones in more slender costa scarcely distinguishable in a surface view, which is also the case of plants from the Russian Far East. In addition, spore size is given as 50-70 $\mu \mathrm{m}$ for Japanese plants (1.c.), whereas in the description of the species in North American Floras it is indicated as 50-70×70-110 $\mu \mathrm{m}$ (Crum \& Anderson, 1980) or 68-120×50-80 $\mu \mathrm{m}$ (Bryan, 2007); Pursell (2002) provides slightly smaller dimensions, $56-90 \times 48-56 \mu \mathrm{m}$, for Central American populations. Smith (2004) gives the same size of spores as Crum \& Anderson (1.c.) for Ireland plants, while Sérgio (2010) describes spores of Spanish plants as much smaller, $60-68 \times 40-55 \mu \mathrm{m}$, which is closer to the size of spores of Russian plants. 


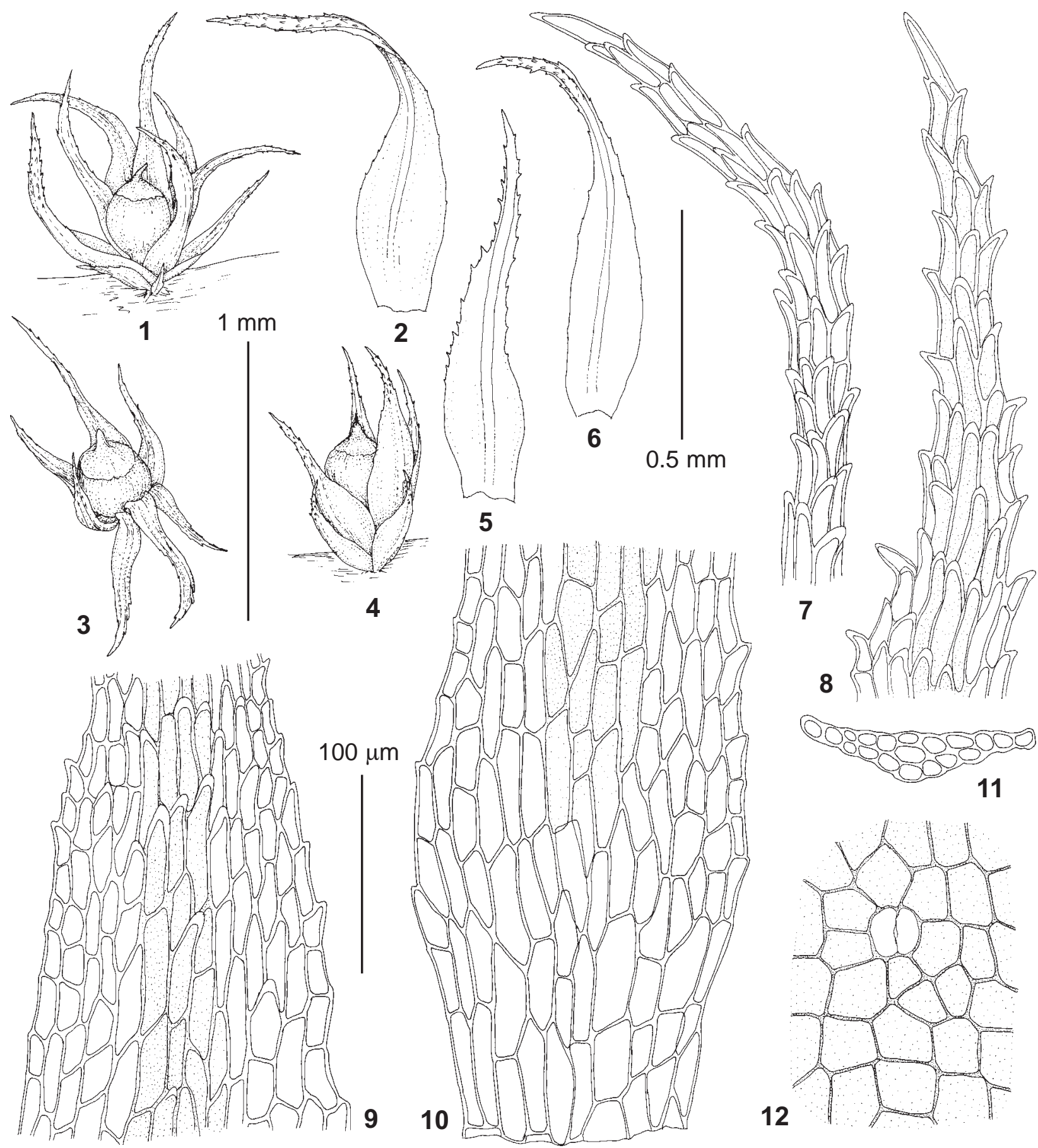

Fig. 6. Ephemerum spinulosum Bruch \& Schimp. (from: Russia, Primorsky Territory, Lozovyj Mt. Range, Ignatov et al. \#1175, MHA): 1, 3-4 - habit, wet; 2, 5-6 - leaves; 7-8 - upper laminal cells; 9 - median laminal cells; 10 - basal laminal cells; 11 - leaf transverse section; 12 - exothecial cells \& stoma. Scale bars: $1 \mathrm{~mm}$ for 1, 3-4; $0.5 \mathrm{~mm}$ for 2, 5-6; $100 \mu \mathrm{m}$ for 7-12.

Differentiation. Ephemerum spinulosum differs from E. serratum, the other species of the genus known in Russia, in presence of costa (absent in the latter species) and strongly protruding upper cell angles on dorsal side of distal lamina and costa, which makes distal parts of leaves spinulose (lamina smooth in E. serratum).

Distribution. Ephemerum spinulosum has its main distribution range in eastern North America, where it is rather common, reaching westward Saskatchewan in Canada and Texas in U.S.A. (Bryan, 2007). Crum \&
Anderson (1981) reported the only locality outside North America in Cuba, where the species was collected in 1911 (NYBG database). Pursell (2002) reported E. spinulosum from Belize, Honduras (in both collected by Allen in 1990s, MO database) and Brasil. The species is know also from Japan, in Honshu and Kyushu, but the first record in this country has been done in late 1970s, the Noguchi' (1974) revision of Ephemeraceae did not include this species. Bryan (2007) and Smith (2004) mention its occurrence in China; however, it is absent in the 


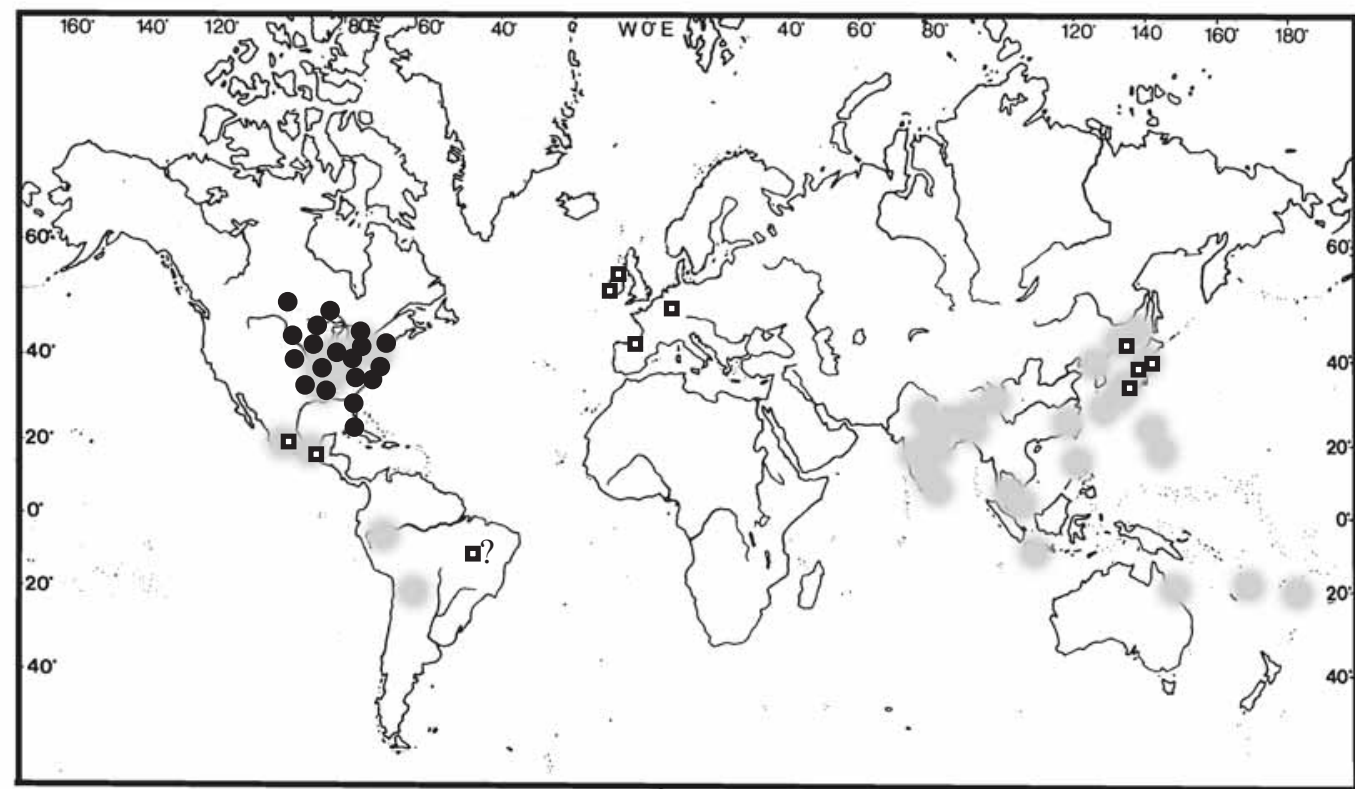

Fig. 7. Distribution of Ephemerum spinulosum. Soild circles indicate region where it was known before 1975 , open squares denote records after 1975. Locality in Brasil is inexact. Shaded is distribution of Fissidens hyalinus (generalized from Ignatov et al., 2007).

Moss Flora of China (Li X.-J. et al., 2003) and Checklist of Chinese mosses (Redfearn et al., 1996).

The first record of E. spinulosum in Europe was made in Northern Ireland in 1999 (Holyoak, 2001) and the second localitywas found in western part of Ireland (Lockhart et al., 2012). After that, E. spinulosum was also collected in Spain and in Germany, in both countries from a single locality: in Álava Province, Northern Spain and in Sauerland, SE part of North Rhine-Westphalia (Sérgio, 2010; Meinunger \& Schröder, 2007).

Two alternative explanations of the new findings are possible. One imply the recent introduction, as it has been suggested by Holyoak (2001). Otherwise, the reason can be an undercollecting, caused by minute plants size and short-term living strategy. There are numerous examples when after an inspired explanation how a neglected species looks and where it has to be searched, the "chain reaction' of its new regional findings proceeds.

The recent introduction of E. spinulosum in Europe seems likely, moreover collections in all four countries were made near the water-bodies, and Holyoak' (2001) idea on spreading by migratory birds seems appropriate. At the same time, in Asia it may be an overlooked species, and thus representing East-East disjunctive pattern similar to that of Fissidens hyalinus (Fig. 7). The habitat where it grows under dense grasses (Figs. 2, 4), on trumpled soil rich in humus is that where one would not expect any interesting moss collection. In addition, the plant is late in its seasonal development, when field-trips activity is usually declining.

\section{ACKNOWLEDGEMENTS}

We thank Oleg Ivanov for sharing photo of Ephemerum spinulosum (Fig. 5), and Benito Tan for reading and commenting the manuscript. The work was partly supported by RAS Program "World Life: Current State and Development".

\section{LITERATURE CITED}

BRYAN, V.S. 2007. Ephemeraceae. - In: Fl. N. Amer. 27. Oxford University Press, New York: 646-653.

CRUM, H.A. \& L.E. ANDERSON 1980. Mosses of Eastern North America. Vol.1. - New York. 663 pp.

HOLYOAK, D.T. 2001. Ephemerum spinulosum Bruch \& Schimp. (Ephemeraceae) in Northern Ireland: a moss new to Europe. -J. Bryol. 23: $139-141$.

IGNATOV, M.S., O.M. AFONINA \& E.A. IGNATOVA (eds.) 2006. Checklist of mosses of East Europe and North Asia. - Arctoa 15: 1-130.

[IGNATOV, M.S. \& E.A. IGNATOVA] ИГНАТОВ M.C., Е.А. ИГНАТОВА 2003. Флора мхов средней части европейской России. Т. 1. - [Moss flora of the Middle European Russia. Vol. 1] M., KMK [Moscow, KMK]. $608 \mathrm{pp}$.

IGNATOV, M.S., T. SUZUKI \& V.Ya. CHERDANTSEVA 2007. Fissidens hyalinus (Fissidentaceae, Bryophyta), a new species for Russia. - Arctoa 16: 123-126.

LI, X.-J., SI HE \& D.-CH. ZHANG 2003. Ephemeraceae. - In: Gao, Ch. \& Si He (eds.). Moss Flora of China. English version. Vol. 3. Grimmiaceae-Tetraphidaeae. Science Press (Beijing, New York) \& Missouri Botanical Garden Press (St. Louis): 77-78.

LOCKHART, N., N. HODGETTS \& D. HOLYOAK 2012. Rare and threatened Bryophytes of Ireland. - Natianal Museums Northern Ireland. $638 \mathrm{pp}$.

MEINUNGER, L. \& W. SCHRÖDER 2007. Verbreitungsatlas Moose Deutschlands. 1-3. - Regensburgische Botanische Gesellschaft, Regensburg, Germany.

NOGUCHI, A. 1974. Musci Japonici. XI. The families Disceliaceae, Ephemeraceae, Oedipodiaceae, Splachnaceae, and Schistostegaceae.J. Hattori Bot. Lab. 38: 387-404.

NOGUCHI, A. \& Z. IWATSUKI 1988. Illustrated Moss Flora of Japan. Vol. 2. - Hattori Bot. Lab., Nichinan: 243-491.

PURSELL, R.A. 2002. Ephemeraceae. -In: Allen, B., D. Hall, J. Muñoz, R.A. Pursell \& W.R. Buck. Moss Flora of Central America. Monogr. Syst. Bot. Missouri Bot. Gard. 90: 244-247.

REDFEARN, P.L.J., B.C. TAN \& SI HE 1996. A newly updated and annotated checklist of Chinese mosses. - J. Hattori Bot. Lab. 79: 163-357.

SÉRGIO, C. 2010. Ephemerum. - In: Guerra, J., M. Brugués, M.J. Cano \& R.M. Cros. Flora Briofitica Ibérica. Vol. IV. Murcia: 16-25.

SMITH, A.J.E. 2004. The moss flora of Britain and Ireland. 2 ed. - Cambridge, Cambridge University Press. $1012 \mathrm{pp}$. 